\title{
Bioavailability of Selenite, Selenomethionine and Selenocystine in Rats with Silver Loading
}

\author{
Munehiro Yoshida, ${ }^{*}$ Hiroyuki Tashiro, ${ }^{* *}$ Kimikazu Iwami, \\ Kyoden Yasumoto and Kazuo IwaI
}

Department of Food Science and Technology, Faculty of Agriculture, Kyoto University, Sakyo-Ku, Kyoto 606, Japan

Received September 20, 1982

\begin{abstract}
Growing rats with silver loading ( $250 \mu \mathrm{g} / \mathrm{g}$ diet as silver acetate) were examined for silver and selenium contents and glutathione peroxidase activities in various tissues. Silver was found at a much higher level in the livers than in the kidneys. Silver loading for 4 weeks caused a decrease in the selenium contents and glutathione peroxidase activities in the tissues without affecting rat growth. Since addition of silver to the diet led to a few-fold increase in fecal selenium excretion, the decreased selenium availability in silver-loaded rats was considered to arise from obstruction of selenium uptake in the intestine. In another experiment, selenite, selenomethionine and selenocystine were administered via intraperitoneal injection $(50 \mu \mathrm{g} / \mathrm{kg}$ once a day for 7 days $)$ to rats previously given silver for 3 weeks. The glutathione peroxidase activities in the livers and kidneys were markedly elevated by the selenium administration, although they were inferior to those in rats not receiving silver. The selenium availability in silver-loaded rats varied with the chemical form of selenium and was to a lesser extent in the case of selenite administration. On the other hand, a significant difference was observed between the rats with and without silver loading regarding the selenium contents in the $105,000 \times g$ pellets of liver and kidney homogenates. The accumulation of selenium there was accompanied by that of silver of about ten or a hundred times as much as selenium in concentration ( $\mu \mathrm{g} / \mathrm{g}$ tissue). Such excess silver accumulation may be explained with the assumption that silver ions undergo reduction by selenite or selenocysteine, but not by selenomethionine, to accumulate as non-charged silver metal within the cells.
\end{abstract}

Since Schwartz and Foltz ${ }^{1)}$ found that selenium had a protective effect against liver necrosis in rats, a number of investigations have been conducted to demonstrate the necessity of this element in animal nutrition. ${ }^{2,3}$ ) It is now believed that selenium plays an important role in prevention of tissues due to oxidative damage in the form of glutathione peroxidase (EC 1.11.1.9). ${ }^{4,5}$ )

Besides being an integral part of glutathione peroxidase, selenium is considered to serve as an antidote or antagonist towards toxic heavy metals such as mercury ${ }^{6)}$ and cadmium. ${ }^{7}$ ) Alternatively, tissue selenium contents may be altered by heavy metal pollution in foods and feeds. Silver, although being less poisonous, is highly antagonistic to selenium in ani- mals. ${ }^{8 \sim 11)}$ Administration of silver at an appropriate level would make it possible to induce selenium deficiency signs in relation to tissue glutathione peroxidase, without impairing other metabolic functions.

The present study was designed to show how addition of silver to a $20 \%$ casein diet affects uptake of dietary selenium and how the bioavailability of selenium administered to silver-loaded rats varies with its chemical form.

\section{MATERIALS AND METHODS}

Male Wistar albino rats weighing 50 to $60 \mathrm{~g}$ were individually housed in stainless wire cages in a temperature $\left(23^{\circ} \mathrm{C}\right)$ - and moisture $(60 \%)$-controlled room with a

* Present address: Department of Public Health, Kansai Medical University, Fumizono-cho, Moriguchi 570, Japan.

** Present address: Technical Research Division, Fujiya Co., Soya, Hatano 257, Japan. 
12 hour light-dark cycle, and were allowed free access to diets and drinking water. The composition of the basal diet was as follows ( $\%$ ): vitamin-free casein, 20; potato starch, 50; sucrose, 15; soybean oil, 8; salt mixture, ${ }^{* 1} 4$; vitamin mixture, ${ }^{* 2} 1$; cellulose powder, 2. After a week feeding, the rats were divided into two groups; one group was fed the basal diet and the other was fed the diet supplemented with $250 \mu \mathrm{g} / \mathrm{g}$ of silver as silver acetate for an additional 4 weeks. Body weight gain and feed consumption for each animal were recorded at 17:00 every day. Feces were collected at 10:00 on the 16th to 21 th days after the beginning of silver loading. During the week of the experimental period before sacrifice, five rats from each group were daily (at 14:00) intraperitoneally injected with $50 \mu \mathrm{g}$ selenium per $\mathrm{kg}$ body weight. Selenium was provided in the form of sodium selenite, selenomethionine or selenocystine.

At the end of the experiment, all rats were killed by decapitation before noon. A freshly drawn blood sample was put into a $10 \mathrm{ml}$ centrifuge tube containing $1 \%$ heparin and centrifuged at $750 \times g$ for $20 \mathrm{~min}$. The erythrocytes, after being twice washed with 5 volumes of $0.25 \mathrm{M}$ sucrose, were burst in a hypotonic solution $(25 \mathrm{~mm}, \mathrm{pH} 7.0$, phosphate buffer) and separated by centrifugation at $105,000 \times g$ for $60 \mathrm{~min}$. Concurrently the tissues (liver, kidney and small intestine) were excised and homogenized with 9 volumes of $0.25 \mathrm{M}$ sucrose in a Teflon-glass homogenizer. The liver and kidney homogenates were further divided into supernatant (soluble) and pellet (insoluble) fractions by centrifugation at $105,000 \times g$ for $60 \mathrm{~min}$.

After digestion of each sample in a mixture of nitric and perchloric acids, selenium was determined fluorometrically according to the method of Watkinson ${ }^{13)}$ and silver was determined by atomic absorption spectrometry. ${ }^{14)}$ Glutathione peroxidase activity was assayed according to the method of Little et al. ${ }^{15)}$ as modified previously. ${ }^{16)}$ The activity was expressed in terms of nmol NADPH oxidized per min per mg protein. Protein was measured according to the method of Lowry et al. as modified by Miller. ${ }^{17}$

Experimental data were statistically tested by variance analysis or the Newman-Keuls multiple range test. ${ }^{18)}$

\section{RESULTS}

When rats were fed for 3 weeks ad libitum the $20 \%$ casein diet, the total food intake and body weight gain amounted to 345 and $143 \mathrm{~g}$ per animal, respectively. These values were

\section{Table I. Silver Contents in Various Tissues OF SilvER-LOADED RATS}

Rats were fed for 4 weeks the $20 \%$ casein diet to which $250 \mu \mathrm{g} \mathrm{Ag} / \mathrm{g}$ of silver acetate was added. Silver was determined in the manner described in MATERIALS AND METHODS. Values are means \pm SEM for 4 animals.

\begin{tabular}{lc}
\hline \multicolumn{1}{c}{ Tissues } & $\begin{array}{c}\text { Silver content } \\
(\mu \mathrm{g} \mathrm{Ag} / \mathrm{g} \text { tissue })\end{array}$ \\
\hline Liver & $18.9 \pm 3.6$ \\
Kidney & $1.3 \pm 0.3$ \\
Small intestine & $14.2 \pm 4.8$ \\
Erythrocyte & $0.3 \pm 0.1$ \\
Plasma & $0.4 \pm 0.1$ \\
\hline
\end{tabular}

Table II. Selenium Contents and Glutathione Peroxidase Activities in Various Tissues of Rats With OR Without Silver LoADiNG

Experimental conditions were the same as in Table I. Selenium content and glutathione peroxidase activity were assayed in the manner described in MATERIALS AND METHODS. Glutathione peroxidase activity is expressed in terms of nmol NADPH oxidized per min per mg protein. Values are means \pm SEM for 4 animals. Significantly different from the control $(-\mathrm{Ag}){ }^{* * *}, p<0.001 ;{ }^{*}, p<0.05$; NS, not significant.

\begin{tabular}{|c|c|c|c|c|}
\hline \multirow{2}{*}{ Tissues } & \multicolumn{2}{|c|}{$\begin{array}{l}\text { Selenium content } \\
\text { (ng/g tissue) }\end{array}$} & \multicolumn{2}{|c|}{$\begin{array}{c}\text { Glutathione peroxidase } \\
\text { activity }\end{array}$} \\
\hline & $-\mathrm{Ag}$ & $+\mathrm{Ag}$ & $-\mathrm{Ag}$ & $+\mathrm{Ag}$ \\
\hline Liver & $120 \pm 20$ & $39 \pm 7 * * *$ & $86 \pm 6$ & $50 \pm 4 * * *$ \\
\hline Kidney & $213 \pm 37$ & $112 \pm 7 * * *$ & $105 \pm 7$ & $30 \pm 7 * * *$ \\
\hline Small intestine & $59 \pm 8$ & $41 \pm 4^{\mathrm{NS}}$ & $60 \pm 12$ & $32 \pm 8^{N S}$ \\
\hline Erythrocyte & $72 \pm 5$ & $53 \pm 4^{*}$ & $162 \pm 15$ & $137 \pm 18^{N S}$ \\
\hline Plasma & $123 \pm 6$ & $37 \pm 4 * * *$ & $27 \pm 1$ & $6 \pm 1 * * *$ \\
\hline \multicolumn{5}{|c|}{${ }^{* 1}$ Harper's salt type B. ${ }^{12)}$} \\
\hline \multicolumn{5}{|c|}{$\begin{array}{l}\text { *2 Obtained from Oriental Yeast Co., Tokyo. Composition }(\mathrm{mg} / \mathrm{kg} \text { diet }) \text { : thiamin } \cdot \mathrm{HCl}, 12 ; \text { riboflavin, } 40 \text {; } \\
\text { idoxine } \cdot \mathrm{HCl}, 8 \text {; cyanocobalamin, } 0.005 \text {; ascorbic acid, } 300 ; p \text {-aminobenzoic acid, } 50 \text {; biotin, } 0.2 ; \text { folic acid, } 2 ; \text { calcium } \\
\text { tothenate, } 50 \text {; niacin, } 60 \text {; inositol, } 60 \text {; choline chloride, } 2000 \text {; retinyl acetate, } 1.72 ; \text { cholecalciferol, } 0.025 ; \alpha \text {-tocopheryl } \\
\text { tate, } 50 \text {; menadione, } 52 \text {; cellulose, } 7312 \text {. }\end{array}$} \\
\hline
\end{tabular}


quite similar to those obtained for silverloaded rats, implying that silver loading at the level of $250 \mu \mathrm{g} \mathrm{Ag} / \mathrm{g}$ diet did not depress rat growth.

Table I shows silver contents in the tissues of rats that had received silver for 4 weeks. Silver accumulated at high levels in the liver and small intestine, but in the kidney and blood to a lesser extent. No morphological change was observed for the liver of silver-loaded rats, despite such high silver accumulation in the tissues.

Table II compares selenium contents and glutathione peroxidase activities in the various tissues of rats with or without silver. The selenium levels in the tissues were greatly lowered by feeding the $20 \%$ casein diet containing as little as 0.030 to $0.045 \mu \mathrm{g} \mathrm{Se} / \mathrm{g}$ diet. Addition of silver to the diet led to a further decrease in the already low selenium levels as well as glutathione peroxidase activities in the liver, kidney and plasma. On the other hand, glutathione levels and activities of glutathione reductase and glucose-6-phosphate dehydrogenase in these tissues remained unchanged irrespective of the presence or absence of dietary silver (data not shown).

Addition of $250 \mu \mathrm{g} / \mathrm{g}$ of silver to the basal diet did not affect the rat appetite as mentioned above. Thus, the daily selenium intake per animal was estimated to be $0.90 \pm 0.01 \mu \mathrm{g}$ $(n=8)$ irrespective of silver loading. As a result of analysis of fecal selenium, about one-fifth of the dietary selenium has shown to be usually excreted in the feces of rats fed the basal diet. ${ }^{19)}$ Selenium is hardly found in the feces of rats fed a non-protein diet, because it mostly occurs in a protein-bound form in the $20 \%$ casein diet. Dietary silver produced a few-fold increase in the fecal selenium excretion, which was comparable to about a half of the dietary selenium. It is probable that dietary silver would combine partly with dietary selenium in the digestive tract and thereby obstruct intestinal absorption of the selenium.

In Table III are shown the availability of various selenium compounds administered by intraperitoneal injection to rats receiving silver or not. Selenium availability was assessed by measuring the hepatic and renal glutathione peroxidase activities which were highly responsive to the selenium status within the body. The enzyme activities in both the tissues were three times as much in control rats as in silver-loaded rats. This observation suggests that silver taken up acts on selenium within the tissues to diminish its availability for synthesis of glutathione peroxidase. In silver-loaded rats, the selenium availability varied depending on the chemical form of injected selenium.

After a week selenium-administration period, the liver and kidney homogenates were assayed for their selenium contents in the soluble and insoluble fractions. The analytical

Table III. Alterations of Hepatic and Renal Glutathione Peroxidase Activities on Selenium Administration in Rats with or without Silver Loading

After rats were fed the $20 \%$ casein diet with or without silver for 3 weeks, selenium compounds were injected intraperitoneally ( $50 \mu \mathrm{g} / \mathrm{kg}$ body weight/day) for 7 days. The enzyme activity is expressed in terms of nmol NADPH oxidized per min per mg protein. Values are means \pm SEM for 5 rats. Means in the same column not sharing a common superscript differ significantly $(p<0.05)$.

Glutathione peroxidase activity

\begin{tabular}{|c|c|c|c|c|}
\hline \multirow[t]{2}{*}{ Selenium injected } & \multicolumn{2}{|c|}{ Liver } & \multicolumn{2}{|c|}{ Kidney } \\
\hline & $-\mathrm{Ag}$ & $+\mathrm{Ag}$ & $-\mathrm{Ag}$ & $+\mathrm{Ag}$ \\
\hline None & $60 \pm 14^{a}$ & $19 \pm 8^{\mathrm{a}}$ & $120 \pm 13^{\mathrm{a}}$ & $37 \pm 5^{\mathrm{a}}$ \\
\hline Sodium selenite & $846 \pm 38^{\mathrm{c}}$ & $54 \pm 5^{\mathrm{ab}}$ & $349 \pm 17^{b}$ & $90 \pm 9^{b}$ \\
\hline Selenomethionine & $727 \pm 43^{b}$ & $253 \pm 17^{c}$ & $332 \pm 13^{b}$ & $164 \pm 8^{c}$ \\
\hline Selenocystine & $683 \pm 12^{b}$ & $103 \pm 10^{\mathrm{b}}$ & $343 \pm 22^{b}$ & $184 \pm 16^{\mathrm{c}}$ \\
\hline
\end{tabular}


data are summarized in Tables IV and V. Similar accumulating effects were observed for selenite, selenomethionine and selenocystine administered to control rats. When administered to silver-loaded rats, selenium accumulated to higher levels in the $105,000 \times g$ pellet than in the supernatant, and also in the kidney pellet than in the liver pellet. Administration of selenocystine caused the highest increase in the selenium content of the kidney pellet. Subsequently, selenomethionine administration was effective. The selenium accumulation on selenite administration was less than that on seleno-amino acid administration, but

\section{Table IV. Effect of Silver Loading on Selenium Accumulation in Liver}

Experimental conditions were the same as in Table III. The supernatant and pellet were obtained by centrifugation at $105,000 \times g$ for $60 \mathrm{~min}$. Values are means $\pm \mathrm{SEM}$ for 5 rats. Means in the same column not sharing a common superscript differ significantly $(p<0.05)$.

\begin{tabular}{|c|c|c|c|c|}
\hline \multirow{3}{*}{ Selenium injected } & \multicolumn{4}{|c|}{ Selenium content ( $\mathrm{ng} / \mathrm{g}$ tissue) } \\
\hline & \multicolumn{2}{|c|}{ Supernatant } & \multicolumn{2}{|c|}{ Pellet } \\
\hline & $-\mathrm{Ag}$ & $+\mathrm{Ag}$ & $-\mathrm{Ag}$ & $+\mathrm{Ag}$ \\
\hline None & $27 \pm 5^{\mathrm{a}}$ & $7 \pm 3^{\mathrm{a}}$ & $59 \pm 3^{a}$ & $42 \pm 3^{a}$ \\
\hline Sodium selenite & $219 \pm 24^{b}$ & $159 \pm 19^{c}$ & $169 \pm 7^{b}$ & $886 \pm 68^{c}$ \\
\hline Selenomethionine & $216 \pm 16^{b}$ & $163 \pm 15^{\mathrm{c}}$ & $148 \pm 7^{\mathrm{b}}$ & $353 \pm 53^{b}$ \\
\hline Selenocystine & $214 \pm 33^{b}$ & $94 \pm 8^{b}$ & $186 \pm 15^{\mathrm{b}}$ & $337 \pm 37^{b}$ \\
\hline
\end{tabular}

Table V. Effect of Silver Loading on Selenium Accumulation in Kidney

Experimental conditions were the same as in Tables III and IV. Values are means \pm SEM for 5 rats. Means in the same column not sharing a common superscript differ significantly $(p<0.05)$.

\begin{tabular}{|c|c|c|c|c|}
\hline \multirow{3}{*}{ Selenium injected } & \multicolumn{4}{|c|}{ Selenium content (ng/g tissue) } \\
\hline & \multicolumn{2}{|c|}{ Supernatant } & \multicolumn{2}{|c|}{ Pellet } \\
\hline & $-\mathrm{Ag}$ & $+\mathrm{Ag}$ & $-\mathrm{Ag}$ & $+\mathrm{Ag}$ \\
\hline None & $63 \pm 2^{\mathrm{a}}$ & $43 \pm 2^{a}$ & $127 \pm 16^{\mathrm{a}}$ & $70 \pm 3^{a}$ \\
\hline Sodium selenite & $204 \pm 17^{b}$ & $92 \pm 9^{a}$ & $270 \pm 23^{b}$ & $850 \pm 74^{b}$ \\
\hline Selenomethionine & $205 \pm 17^{b}$ & $184 \pm 16^{b}$ & $315 \pm 19^{b}$ & $1141 \pm 138^{b}$ \\
\hline Selenocystine & $245 \pm 32^{b}$ & $262 \pm 30^{c}$ & $293 \pm 36^{b}$ & $5730 \pm 387^{\mathrm{c}}$ \\
\hline
\end{tabular}

Table VI. Effect of Selenium Administration on Silver Accumulation IN LIVER AND KIDNEY

Experimental conditions were the same as in Tables III, IV and V. Values are means \pm SEM for 5 rats. Means in the same column not sharing a common superscript differ significantly $(p<0.05)$.

\begin{tabular}{|c|c|c|c|c|}
\hline \multirow{3}{*}{ Selenium injected } & \multicolumn{4}{|c|}{ Silver content $(\mu \mathrm{g} / \mathrm{g}$ tissue $)$} \\
\hline & \multicolumn{2}{|c|}{ Liver } & \multicolumn{2}{|c|}{ Kidney } \\
\hline & Supernatant & Pellet & Supernatant & Pellet \\
\hline None & $3.9 \pm 0.7^{\mathrm{a}}$ & $14.9 \pm 3.2^{\mathrm{a}}$ & $0.2 \pm 0.1^{\mathrm{a}}$ & $1.2 \pm 0.1^{\mathrm{a}}$ \\
\hline Sodium selenite & $8.0 \pm 0.9^{\mathrm{a}}$ & $80.0 \pm 10.2^{\mathrm{c}}$ & $0.2 \pm 0.1^{\mathrm{a}}$ & $11.6 \pm 1.3^{\mathrm{b}}$ \\
\hline Selenomethionine & $8.1 \pm 1.9^{\mathrm{a}}$ & $34.2 \pm 3.8^{\mathrm{b}}$ & $0.3 \pm 0.1^{\mathrm{a}}$ & $16.6 \pm 1.3^{\mathrm{b}}$ \\
\hline Selenocystine & $8.5 \pm 2.0^{\mathrm{a}}$ & $41.2 \pm 4.3^{\mathrm{b}}$ & $0.7 \pm 0.1^{b}$ & $49.7 \pm 3.7^{\mathrm{c}}$ \\
\hline
\end{tabular}


the reverse was observed for the selenium accumulation in the liver pellet. The glutathione peroxidase activity levels did not necessarily reflect the selenium contents in the tissues of silver-loaded rats.

Administration of selenium to silver-loaded rats markedly raised tissue accumulation of both selenium and silver. The effects of various selenium compounds on silver accumulation in the liver and kidney are presented in Table VI. About eight to fifteen times as much silver as selenium by concentration ( $\mu \mathrm{g} / \mathrm{g}$ tissue) was found in the kidney pellet. Similarly, silver accumulation in the liver pellet was far higher than that of selenium. In particular, the $\mathrm{Ag} / \mathrm{Se}$ ratio of the liver pellet reached about a hundred in the case of selenite administration. An insoluble complex between selenium and silver, if it exists at all, is present in a trace amount. It thus seems likely that silver accumulates in the form of insoluble non-charged metal in the tissues.

\section{DISCUSSION}

Antagonism between silver and selenium has been shown by many investigators. ${ }^{8 \sim 11)}$ Diplock et $a .^{8,9)}$ found that selenium deficiency was induced in rats and chicks by administration of silver acetate in drinking water. And Jensen et al. ${ }^{20,21)}$ observed that addition of $900 \mu \mathrm{g} / \mathrm{g}$ of silver to practical diets for turkey poults and chicks resulted in reduced growth and cardiac enlargement. On the other hand, Wagner et al. ${ }^{10)}$ reported that a high level of silver in drinking water depressed growth and survival of rats fed low-selenium and vitamin E-deficient diets and that silver toxicity was alleviated by selenium supplementation. We also confirmed that dietary silver $(250 \mu \mathrm{g} / \mathrm{g}$ diet $)$ raised fecal selenium excretion and thereby caused a considerable decrease in tissue selenium content and glutathione peroxidase activity without affecting rat growth. The $20 \%$ casein diet used throughout this experiment was marginal in selenium. Thus, the inconsistency between this and the previous observation for rat growth would be due to the difference in the daily dose amount of silver rather than in the animal species. With respect to the antagonistic effect of dietary silver on selenium availability, the hepatic glutathione peroxidase activity in rats fed a casein diet with adequate selenium and vitamin $\mathrm{E}$ has been observed to be reduced to $5 \%$ of the control by administration of $751 \mu \mathrm{g} / \mathrm{g}$ of silver in drinking water. $^{10)}$ Similarly, in this experiment, dietary silver has proven to depress the availability of intraperitoneally injected (not orally administered) selenium for synthesis of glutathione peroxidase in the rat liver and kidney (Table III); indicating that silver does not only interfere with selenium absorption in the intestinal tract. but with selenium metabolism in the tissues as well. It can be pointed out in this connection that sixty times as much silver is accumulated in the liver as in the blood (Table I).

Recently, Flegal et al. ${ }^{22)}$ demonstrated that selenium retention in swine tissue was markedly affected by dietary cadmium probably due to interference with intestinal absorption of dietary selenium. It is well-known that selenium decreases mercury toxicity, ${ }^{6,23,24)}$ and that simultaneously injected sodium selenite and mercuric chloride both accumulate at higher concentrations, than when independently administered, and in a $1: 1$ molar ratio in the plasma. ${ }^{25}$ 27) Selenium and mercury seem to be attached to the plasma protein through a sulfhydryl group. ${ }^{26)}$ When silver-loaded rats were injected with various selenium compounds, tissue accumulation of selenium and silver varied with the chemical form of selenium (Tables IV, V and VI). Selenite within the body turns out to be a selenotrisulfide via linkage with glutathione or other sulfhydryls. ${ }^{28)}$ Hence it appears likely that injected selenite reacts with intracellular silver ions to accumulate as insoluble $\mathrm{Ag}_{2} \mathrm{Se}$ in the cells. The formation of such an insoluble compound alone cannot account for the several-fold increase in silver accumulation in the tissues of rats given selenite, because silver is found at a higher concentration than selenium in both the hepatic and renal insoluble fractions. A plau- 
sible explanation for this phenomenon is that conversion of selenite to selenide in the cells is accompanied by precipitation of excess metalline silver. Factors influencing silver accumulation are not confined to inorganic selenium. Seleno-amino acids also raised silver accumulation in the tissues to a considerable extent. Although cystine per se can hardly react with metal ions, selenocystine is similarly reactive as cysteine. ${ }^{29)}$ In addition, selenocystine is considered to be rapidly converted to selenocysteine in the vital cells under reductive circumstances. The very high accumulation of the selenium from selenocystine in the renal insoluble fraction may be partly explained by assuming that injected selenocystine would react with accumulating silver in the liver to form a mercaptide-like complex, which would undergo re-absorption in the kidney.

Selenomethionine is obviously inferior to selenocystine (or selenocysteine) in reactivity with metal ions. Methionine can rarely be replaced by selenomethionine for protein synthesis, ${ }^{30}$ ) but selenocysteine is involved in the only identified selenium-containing functional protein in animals, i.e. glutathione peroxidase. ${ }^{31)}$ Whatever form of selenium is administered, the main selenium metabolite excreted in the urine is the trimethylselenonium ion. ${ }^{32}$ These facts suggested that selenomethionine shared the metabolic pathway with selenocysteine. In practice, there is evidence to show that the conversion of selenomethionine to selenocysteine is mediated by a pyridoxal phosphate-dependent enzyme system. ${ }^{33,34)}$ Selenomethionine should be metabolized to either selenocysteine or selenide prior to incorporation into the glutathione peroxidase molecule. Nevertheless, selenomethionine was the most effective for synthesis of glutathione peroxidase in the rat liver with silver. This is presumably because selenomethionine would be hard to combine with accumulating silver in the liver unless metabolized. The effect of dietary silver that counteracts the availability of injected selenomethionine can be interpreted in terms of interaction between intracellular silver ions and selenomethionine- metabolic product(s).

The purpose of this investigation was in part to determine to what extent the availability of chemically different selenium is affected by dietary silver and to obtain information on alteration of the availability of dietary selenium with environmental pollution. Selenium mainly occurs in the form of selenomethionine in plant proteins ${ }^{35,36)}$ and in the form of a selenotrisulfide and/or selenocystine in meat and meaty products. ${ }^{36,37)}$ A large part of nutritionally important selenium is taken in from these food proteins. For this reason, it is concluded that contamination of foodstuffs by a trace amount of a heavy metal does not induce selenium deficiency signs.

In rat liver without silver, inorganic selenium was more effective for selenium availability than seleno-amino acids, despite their similarity in tissue accumulation. It seems reasonable to presume a mechanism by which selenide derived from selenite ${ }^{28)}$ or selenocysteine $^{38)}$ may be available for synthesis of glutathione peroxidase, so as to explain the predominance of inorganic selenium over selenoamino acids. Further experimental data are required to prove this hypothesis.

\section{REFERENCES}

1) K. Schwartz and C. M. Foltz, J. Am. Chem. Soc., 79, 3292 (1957).

2) J. N. Thompson and M. L. Scott, J. Nutr., 97, 335 (1969).

3) K. E. M. McCoy and P. H. Weswig, J. Nutr., 98, 983 (1969).

4) J. T. Rotruck, A. L. Pope, H. E. Ganther, A. B. Swanson, D. G. Hafeman and W. G. Hoekstra, Science, 179, 588 (1973).

5) T. Noguchi, A. H. Cantor and M. L. Scott, J. Nutr., 103, 1502 (1973).

6) J. Parizek and I. Ostadalova, Experientia, 23, 142 (1967).

7) S. A. Gunn, T. C. Gould and W. A. D. Anderson, Proc. Soc. Exp. Biol. Med., 128, 591 (1968).

8) A. T. Diplock, J. Green, J. Bunyan, D. Mchale and I. R. Muthy, Brit. J. Nutr., 21, 115 (1967).

9) J. Bunyan, A. T. Diplock, M. A. Cawthrone and J. Green, Brit. J. Nutr., 22, 165 (1968).

10) P. A. Wagner, W. G. Hoekstra and H. E. Ganther, Proc. Soc. Exp. Biol. Med., 148, 1106 (1975).

11) L. S. Jensen, J. Nutr., 105, 769 (1975). 
12) A. E. Harper, J. Nutr., 68, 405 (1959).

13) J. H. Watkinson, Anal. Chem., 38, 92 (1966).

14) M. C. Greaves, Nature, 199, 552 (1963).

15) C. Little, R. Olinescue, K. C. Reid and P. J. O'Brien, J. Biol. Chem., 245, 3632 (1970).

16) M. Yoshida, K. Yasumoto, K. Iwami and $\mathrm{H}$. Tashiro, Agric. Biol. Chem., 45, 1681 (1981).

17) G. L. Miller, Anal. Chem., 31, 964 (1959).

18) C. W. Snedecor and W. G. Cochran, "Statistical Methods," 6th Ed., Iowa State University Press, Ames, 1967, Chapter 10.

19) M. Yoshida, K. Iwami, K. Yasumoto and K. Iwai, Nippon Nôgeikagaku Kaishi, 55, 689 (1981).

20) L. S. Jensen, R. P. Petersen and L. Falen, Poultry Sci., 53, 57 (1974).

21) R. P. Petersen and L. S. Jensen, Poultry Sci., 54, 795 (1975).

22) K. M. Flegal, E. E. Cary, W. G. Pond and L. P. Krook, J. Nutr., 110, 1255 (1980).

23) H. E. Ganther, M. L. Sunde, M. J. Kopecky, P. A. Wagner, S-H, Oh and W. G. Hoekstra, Science, 175, 1122 (1972).

24) S. Potter and G. Matrone, J. Nutr., 104, 638 (1974).

25) V. Eybl, J. Sykora and F. Mertl, Arch. Toxicol., 25, 296 (1969).

26) R. F. Burk, K. A. Foster, P. M. Greenfield and K. W. Kiker, Proc. Soc. Exp. Biol. Med., 145, 782
(1974).

27) K. Komiya, I. Koike and S. Kawauchi, Eisei Kagaku, 23, 244 (1977).

28) H. S. Hsieh and H. E. Ganther, Biochemistry, 14, 1632 (1975).

29) Y. Sugiura, Y. Tamai and H. Tanaka, Bioinorg. Chem., 9, 167 (1978).

30) A. Ochoa-Solano and C. Gilter, J. Nutr., 98, 243 (1968).

31) J. W. Forstrom, J. J. Zakowski and A. L. Tappel, Biochemistry, 17, 2639 (1978).

32) K. W. Kiker and R. F. Burk, Am. J. Physiol., 227, 643 (1974).

33) K. Yasumoto, K. Iwami and M. Yoshida, J. Nutr., 109, 760 (1979).

34) N. Esaki, T. Nakamura, H. Tanaka, T. Suzuki, Y. Morino and K. Soda, Biochemistry, 20, 4492 (1981).

35) O. E. Olson, E. J. Novacek, E. I. Whitehead and I. S. Palmer, Phytochemistry, 9, 1181 (1970).

36) National Research Council, "Selenium," National Academy of Science, Washington, D. C., 1976, pp. $51 \sim 74$.

37) O. A. Levander, "Trace Elements in Human Health and Disease," Vol. II, ed. by A. S. Prasad, Ačademic Press, New York, N. Y., 1976, pp. 135 163.

38) N. Esaki, T. Nakamura, H. Tanaka and K. Soda, J. Biol. Chem., 257, 4386 (1982). 